\title{
A RECUPERAÇÃO JUDICIAL DO EMPRESÁRIO RURAL PESSOA FÍSICA: NECESSIDADE DE PRAZO MÍNIMO DE INSCRIÇÃO NO REGISTRO PÚBLICO DE EMPRESAS MERCANTIS
}

\author{
Roberto Lincoln Gomes Júnior \\ Centro Universitário 7 de Setembro - UNI7, Ceará \\ Ernani Soares \\ Universidade Federal do Ceará - UFC, Ceará
}

\begin{abstract}
RESUMO: O presente artigo tem como objetivo analisar se o empresário rural pessoa física, registrado há menos de dois anos no Registro Público de Empresas Mercantis, mas que exerce atividade empresária por período superior a dois anos, poderá pedir recuperação judicial e ter deferido o processamento do benefício. Para tanto, traça-se um breve contexto da evolução das teorias do direito comercial, especialmente a teoria da empresa, adotada pelo Código Civil, e a disciplina do empresário rural. Empós, busca-se interpretar e comentar a intepretação que os tribunais pátrios e a doutrina conferem ao caput do artigo 48 da Lei no 11.101/2005, o qual exige que o devedor exerça regularmente suas atividades há mais de dois anos à data do pedido para poder pedir recuperação judicial. Também são examinados projetos de lei existentes que tratam da questão, especificamente o Projeto de Lei ${ }^{\circ}$ 6.279/2013 e o Projeto de Lei ${ }^{\circ} 10.220 / 2018$. Ao final, conclui-se que, apesar da controvérsia existente, o empresário rural pessoa física, registrado há menos de dois anos no Registro Público de Empresas Mercantis, mas que exerce atividade empresária por período superior a dois anos, pode pedir recuperação judicial e ter deferido o processamento do benefício.
\end{abstract}

PALAVRAS-CHAVE: Direito comercial. Recuperação judicial. Empresário rural.

\section{The Judicial Recovery of the Rural Entrepreneur: Minimum Time Required for Registration in the Public Registry of Mercantile Companies}

\begin{abstract}
The purpose of this article is to analyze if the rural entrepreneur, registered less than two years in the Public Register of Mercantile Companies, but who carries out business activity for a period of more than two years, may request judicial recovery and have deferred processing of the benefit. In order to do so, a brief context of the evolution of theories of commercial law is drawn, especially the theory of the company, adopted by the Civil Code, and the discipline of the rural entrepreneur. After, it seeks to interpret and comment on the interpretation that the courts of law and doctrine confer on Article 48 of Law 11,101 / 2005, which requires that the debtor regularly carries out his activities more than two years before the date of the request for to seek judicial recovery. Existing bills dealing with the issue are also examined, specifically Bill 6,279 / 2013 and Bill 10,220 / 2018. In the end, it is concluded that, despite the existing controversy, the rural entrepreneur, registered less than two years ago in the Public Register of Mercantile Companies, but who carries on business for more than two years, can request judicial recovery and processing of the benefit.
\end{abstract}

KEYWORDS: Commercial Law. Judicial Recovery. Rural entrepreneur. 
A recuperação judicial do empresário rural pessoa física: necessidade de prazo mínimo de inscrição no registro público de empresas mercantis

\section{INTRODUÇÃO}

O presente artigo tem como objetivo analisar se o empresário rural pessoa física, registrado há menos de dois anos no Registro Público de Empresas Mercantis, mas que exerce atividade empresária por período superior a dois anos, poderá pedir recuperação judicial e ter deferido o processamento do benefício. Pretende-se, portanto, interpretar e comentar a intepretação que os tribunais pátrios e a doutrina conferem ao art. 48 da Lei no 11.101/2005 ("Lei de Recuperações e Falências", ou simplesmente "LRF"), o qual exige que o devedor exerça regularmente suas atividades há mais de dois anos à data do pedido para poder pedir recuperação judicial.

A controvérsia, existente tanto na jurisprudência quanto na doutrina, dá-se porque, para uma corrente, o exercício regular da atividade empresária rural ${ }^{1}$ tem início com a inscrição do empresário no Registro Público de Empresas Mercantis; para outra, o exercício regular da atividade empresária rural prescinde do registro, iniciando-se no momento em que se façam presentes os requisitos para a caracterização de uma atividade como empresária (art. 966, caput, do Código Civil).

Conforme será exposto, atualmente, o Superior Tribunal de Justiça (STJ) ainda não possui entendimento definitivo sobre a matéria, mas tão somente decisões individuais e posicionamentos isolados, estando pendente o julgamento de diversos recursos especiais sobre a matéria.

A relevância do tema pode ser demonstrada, mais do que pela ausência de uma posição consolidada dos tribunais superiores, pela própria relevância das atividades ligadas ao agronegócio no Brasil, que corresponde a 23,6\% do Produto Interno Bruto (PIB) brasileiro ${ }^{2}$, e, ainda considerando o cenário econômico adverso encontrado nos últimos anos, pelo grande número de empresários rurais em dificuldade financeira - apesar de o setor se sobressair frente aos demais ${ }^{3}$ -, os quais poderiam se utilizar do instituto da recuperação judicial para a reestruturação da sua atividade e para a manutenção de sua função social.

\footnotetext{
1 A Instrução Normativa SRF 83/2001, da Secretaria da Receita Federal, que dispõe sobre a tributação dos resultados da atividade rural das pessoas físicas, considera como atividade rural, em seu art. $2^{\circ}: i$ ) agricultura; ii) pecuária; iii) extração e a exploração vegetal e animal; $i v$ ) apicultura; $v$ ) avicultura; vi) cunicultura; vii) suinocultura; viii) sericicultura; $i x$ ) piscicultura e outras culturas de pequenos animais; $x$ ) captura de pescado com características artesanais; $x i$ ) transformação de produtos decorrentes da atividade rural, sem que sejam alteradas as características do produto in natura, feita pelo próprio agricultor ou criador, utilizando exclusivamente matéria-prima produzida na área rural explorada, tais como: $a$ ) beneficiamento e transformação de produtos agrícolas, zootécnicos e florestais; e $b$ ) produção de embriões de rebanho em geral, alevinos e girinos, em propriedade rural, independentemente de sua destinação (reprodução ou comercialização). Considera-se, também, atividade rural, nos termos do art. 59 da Lei n 9.430/1996, o cultivo de florestas que se destinem ao corte para comercialização, consumo ou industrialização. Sobre as atividades que não consistem em atividades rurais, veja-se o art. $4^{\circ}$ da Instrução Normativa SRF 83/2001, da Secretaria da Receita Federal. BRASIL. Receita Federal. Instrução Normativa no 83 de 16 de outubro de 2001. Disponível em: http:// normas.receita.fazenda.gov.br/sijut2consulta/link.action?visao=anotado\&idAto=14387. Acesso em: 31 mar. 2019.

2 CONFEDERAÇÃO DA AGRICULTURA E PECUÁRIA NO BRASIL. Panorama do Agro. Disponível em: https:/ /www.cnabrasil.org.br/cna/panorama-do-agro. Acesso em: 27 mar. 2019.

3 Desde 2007, excetuando-se em 2014, o superávit comercial do agronegócio brasileiro tem mais que superado o déficit comercial dos demais setores da economia brasileira e garantido sucessivos superávits à balança comercial brasileira. Além disso, em 2014, a participação do agronegócio no PIB brasileiro consistia em 20,4\%, aumentando para 21,4\% em 2015 e 23,6\% em 2016. CONFEDERAÇÃO DA AGRICULTURA E PECUÁRIA NO BRASIL. Panorama do Agro. Disponível em: https://www.cnabrasil.org.br/cna/panorama-do-agro. Acesso em: 27 mar. 2019.
} 


\section{A CARACTERIZAÇÃo dO EMPRESÁrio E O PRODUTOR RURAL}

Após passar por sucessivas fases, respectivamente, as fases subjetiva ${ }^{4}$ e objetiva ${ }^{5}$, o direito comercial retornou ao critério subjetivo de avaliação da atividade comercial ${ }^{6}$, sendo aplicado àqueles que exercem a empresa, esta no seu perfil funcional (atividade), conforme descrito por Alberto Asquini ${ }^{7}$.

Ao adotar como inspiração o Codice italiano de 1942, que consagrou a teoria apontada acima, o Código Civil Brasileiro de 2002 (“CC/2002”), em seu art. 966, caput, previu que o empresário é quem "exerce profissionalmente atividade econômica organizada para a produção ou a circulação de bens ou de serviços".

Assim, depreende-se que empresa, em seu perfil funcional, seria atividade econômica organizada para a produção ou a circulação de bens ou de serviços.

Consoante dispõe Tullio Ascarelli ${ }^{8}$, a atividade efetivamente exercida constitui um fato, e um fato para cuja relevância jurídica a vontade do sujeito é indiferente, não só quanto às consequências. Também como destaca Erasmo Valladão Azevedo e Novaes França ${ }^{9}$, atividade empresária é um fato jurídico, pois quem a exerce está sujeito ao regime jurídico do empresário, independentemente de sua vontade; ou seja, quem exerce atividade de empresário, independentemente de sua vontade, está sujeito ao regime jurídico do empresário.

Enquanto fato, portanto, a atividade não pode ser considerada nula ou inválida, atributos exclusivos dos atos, mas tão somente lícitas ou ilícitas, regulares ou irregulares ${ }^{10}$. Daí porque o empresário que exerce atividade empresária, sem registro, mesmo o art. 967 do CC/2002 obrigando-lhe a fazer previamente ao início do exercício de empresa, é tido como empresário irregular, não sendo ignoradas eventuais obrigações assumidas no exercício da atividade.

Para o empresário rural, todavia, foi previsto um regime distinto de todos os outros. Conforme preleciona o art. 971 do CC/2002, "o empresário, cuja atividade rural constitua sua principal profissão, pode, observadas as formalidades de que tratam o art. 968 e seus parágrafos, requerer inscrição no Registro Público de Empresas Mercantis da respectiva sede, caso em que, depois de inscrito, ficará equiparado, para todos os efeitos, ao empresário sujeito a registro". Percebe-se, portanto, que, para o empresário rural, o registro consiste em uma faculdade, a qual, se exercida, equiparar-lhe-á ao empresário sujeito a registro.

4 Período em que o direito comercial seria aplicado àqueles que estivessem registrados em corporação de artes e ofícios. Ver: ASCARELLI, Tullio. Origem do direito comercial. Revista de Direito Mercantil, n. 103, pp. 87-100, jul./set., 1996.

5 Período em que o direito comercial seria aplicado àqueles que praticassem costumeiramente atos de comércio. Ver: CAVALli, Cássio. Direito Comercial: Passado, Presente e Futuro. Rio de Janeiro: Elsevier, 2012, pp. 65-79.

6 ALMEIDA, Betyna Ribeiro de. Aspectos da teoria jurídica da empresa. Revista de Direito Mercantil, n. 119, pp. 236-254, jul./set., 2000, p. 237.

7 Ver: COMPARATO, Fábio Konder. Perfis da Empresa. Revista de Direito Mercantil, n. 104, pp. 116-117, out./dez., 1996. Tradução do original: ASQUINI, Alberto. Profilli dell'impresa. Rivista di Diritto Commerciale, 1943, v. 41, I.

8 ASCARELLI, Tullio. O empresário. Revista de Direito Mercantil, n. 109, jan./mar., pp. 183/189, 1998 , p. 187.

9 FRANÇA, Erasmo Valladão Azevedo e Novaes. Empresa, Empresário e Estabelecimento: A Nova Disciplina das Sociedades. In: Temas de Direito Societário, Falimentar e Teoria da Empresa. São Paulo: Malheiros Editores, 2009, p. 518.

${ }^{10}$ FRANÇA, Erasmo Valladão Azevedo e Novaes. Empresa, Empresário e Estabelecimento: A Nova Disciplina das Sociedades. In: Temas de Direito Societário, Falimentar e Teoria da Empresa. São Paulo: Malheiros Editores, 2009 , p. 519. 
A recuperação judicial do empresário rural pessoa física: necessidade de prazo mínimo de inscrição no registro público de empresas mercantis

Disso surgem duas controvérsias: enquanto não efetuar a inscrição perante o Registro Público de Empresas Mercantis, o empresário rural consiste, ou não, em empresário; e, ao exercer atividade empresária sem a inscrição no Registro Público de Empresas Mercantis, a atividade exercida pelo empresário rural se configura, ou não, como regular.

A primeira controvérsia cinge-se à discussão sobre a natureza do registro facultado ao empresário rural, se constitutivo ou declaratório.

Alfredo de Assis Gonçalves Neto afirma que a inscrição do empresário rural será constitutiva da qualidade de empresário porque se erige em ato determinante de sua sujeição ao regime jurídico do direito de empresa ${ }^{11}$.

Gustavo Saad Diniz ${ }^{12}$, por seu turno, defende que, pelo teor do art. 971 do CC/2002, o produtor rural já é considerado empresário; o registro, facultativo, serviria à equiparação ao empresário comum para todos os fins ${ }^{13}$.

Defende-se, aqui, que o registro seja uma faculdade ao produtor rural que atende às condições do art. 966, caput, do CC/2002, para que se equipare ao regime jurídico do empresário comum. Daí porque o próprio art. 971 do CC/2002 já faz menção ao 'empresário, cuja atividade rural constitua sua principal profissão'. Ou seja, para o CC/2002, o agente que exerça profissionalmente atividade econômica organizada para a produção ou a circulação de bens ou de serviços, de cunho rural, é empresário, independente do registro, servindo este para sua equiparação ao empresário ao empresário comum para todos os efeitos.

Quanto à regularidade, ou não, da atividade exercida pelo empresário rural sem registro, em virtude de a inscrição ser uma faculdade ao empresário rural, e não uma obrigação, não se cogita classificar sua atividade como irregular.

Nesse sentido, Ivo Waisberg aponta que "[a] falta de registro, por outro lado, não impede a qualificação de sua atividade como empresarial nem a regularidade desta atividade"14. Manoel Justino Bezerra Filho ${ }^{15}$, do mesmo modo, destaca que a inscrição no Registro Público de Empresas Mercantis não é elemento regularizador da atividade, mas apenas elemento de mudança da conceituação da atividade, que era civil e passa a ser empresária.

Assim, diferente do empresário comum, cuja atividade, caso não tenha havido a inscrição - obrigatória - no Registro Público de Empresas Mercantis, reputa-se irregular, o empresário rural, se não tiver feito sua inscrição - facultativa -, exerce atividade empresária regularmente. Mesmo que se entendesse que o registro, no caso, teria natureza constitutiva, não se cogitaria falar em irregularidade da atividade empresária, justamente por inexistir atividade empresária,

${ }^{11}$ GONÇALVES NETO, Alfredo de Assis. Direito de empresa: Comentários aos arts. 966 a 1.195. 6. ed. São Paulo: Revista dos Tribunais, 2016, n. XVII, pp. 60-61.

12 DINIZ, Gustavo Saad. Produtor rural. Enciclopédia jurídica da PUC-SP. Celso Fernandes Campilongo, Alvaro de Azevedo Gonzaga e André Luiz Freire (coords.). Tomo: Direito Comercial. Fábio Ulhoa Coelho, Marcus Elidius Michelli de Almeida (coord. de tomo). 1. ed. São Paulo: Pontifícia Universidade Católica de São Paulo, 2017. Disponível em: https://enciclopediajuridica.pucsp.br/verbete/211/edicao-1/produtor-rural. Acesso em: 28 mar. 2019.

13 Opinião também compartilhada por Ivo Waisberg, para quem: “[s]e o empresário rural optar por se registrar, então será equiparado, para todos os efeitos, ao empresário não rural sujeito a registro, aplicando-se a ele, integralmente, o regime jurídico empresarial, sem qualquer distinção e nas mesmas condições aplicadas a qualquer outro empresário. A falta de registro, por outro lado, não impede a qualificação de sua atividade como empresarial". WAISBERG, Ivo. A Viabilidade da Recuperação Judicial do Produtor Rural. Revista do Advogado. Ano XXXVI, out./2016, n. 131, pp. 83-90, 2016, p. 86.

14 WAISBERG, Ivo. A Viabilidade da Recuperação Judicial do Produtor Rural. Revista do Advogado. Ano XXXVI, out./2016, n. 131, pp. 83-90, 2016, p. 86.

15 BEZERRA FILHO, Manoel Justino. Lei de Recuperação de Empresas e Falência: Lei 11.101/2005. Comentada artigo por artigo. 11. ed. São Paulo: Revista dos Tribunais, 2016, p. 157. 
mas tão somente atividade civil. Desse modo, seja qual for o entendimento acerca da natureza do registro para o empresário rural - constitutivo ou declaratório -, não cabe reputar como irregular o exercício da atividade empresária pelo empresário rural que não efetuou sua inscrição no Registro Público de Empresas Mercantis.

\section{A RECUPERAÇÃO JUDICIAL DO EMPRESÁRIO RURAL PESSOA FÍSICA}

Conforme indicador do Serasa Experian ${ }^{16}, 2018$ foi o ano em que mais empresários e sociedades empresárias do setor primário pediram recuperação judicial desde a criação do instituto, com a edição da Lei no 11.101/2005. Foram 94 requerimentos em 2018, contra 47 em 2017, 93 em 2016, 44 em 2015 e 29 em 2014, apenas para citar os últimos cinco anos.

Em que pese 'setor primário' não corresponder exclusivamente às atividades rurais, ao englobar, por exemplo, as atividades de mineração, o dado informado acima é um indicativo de que cada vez mais empresários e sociedades empresárias cuja atividade-fim seja rural estão recorrendo à recuperação judicial para a superação do estado de crise econômica-financeira.

Nesse sentido, destaque-se, primeiramente, que a Lei $\mathrm{n}^{\circ} 11.101 / 2005$ não veda a utilização do instituto por empresários ou sociedades empresárias rurais. Em seu art. $2^{\circ}$, a Lei n ${ }^{\circ} 11.101 /$ 2005 impede o acesso ao instituto da recuperação judicial às empresas públicas, sociedades de economia mista, instituições financeiras públicas ou privadas, cooperativas de crédito, consórcios, entidades de previdência complementar, sociedades operadoras de plano de assistência à saúde, sociedades seguradoras, sociedades de capitalização e outras entidades legalmente equiparadas às anteriores. Não há qualquer vedação expressa, portanto, aos empresários e sociedades empresárias que exerçam atividade empresária rural.

Em contrapartida, a Lei $\mathrm{n}^{\circ} 11.101 / 2005$, em seu art. $1^{\mathrm{o}}$, prevê a possibilidade de que quaisquer empresários ou sociedades empresárias, excetuando-se os listados acima, possam se utilizar da recuperação judicial, sendo intitulados de 'devedor'.

No art. 48, caput, a Lei $\mathrm{n}^{\circ} 11.101 / 2005$ exige que o devedor, para requerer recuperação judicial, exerça regularmente suas atividades há mais de dois anos. Faculta-se, no $\S 2^{\circ}$ do mesmo art. 48 da Lei $\mathrm{n}^{\circ} 11.101 / 2005$, que o empresário rural pessoa jurídica comprove o prazo estabelecido no caput por meio da Declaração de Informações Econômico-fiscais da Pessoa Jurídica (DIPJ) que tenha sido entregue tempestivamente.

Por fim, no que importa ao estudo do tema, o art. 51, inc. V, da Lei ${ }^{\circ}$ 11.101/2005 dispõe como um dos documentos essenciais à instrução do pedido de recuperação judicial a certidão de regularidade do devedor no Registro Público de Empresas Mercantis.

Diante do exposto, observam-se basicamente três exigências: para requerer recuperação judicial, o devedor deverá ser empresário ou sociedade empresária, deverá estar inscrito no Registro Público de Empresas Mercantis - pois somente quem ali está registrado obtém certidão de regularidade do órgão - e deverá comprovar o exercício regular de suas atividades por mais de dois anos.

${ }^{16}$ SERASA EXPERIAN. Indicadores Econômicos: Recuperações Judiciais Requeridas. Disponível em: https://s3-saeast-1.amazonaws.com/serasaexperian-site-institucional-wp-content/wp-content/uploads/2019/03/12124217/FACONS.zip. Acesso em: 29 mar. 2019. 
A recuperação judicial do empresário rural pessoa física: necessidade de prazo mínimo de inscrição no registro público de empresas mercantis

Em que pese a exigência do art. 51, inc. V, da Lei $\mathrm{n}^{\circ}$ 11.101/2005, registre-se, aqui, que, na ocasião do julgamento do Recurso Especial no 1.193.115/MT pelo Superior Tribunal de Justiça (STJ), a Ministra Nancy Andrighi, ora na relatoria do recurso, votou pelo seu provimento, defendendo a possibilidade de produtores rurais, não registrados no Registro Público de Empresas Mercantis à data do pedido de recuperação judicial, ajuizarem e terem deferida a recuperação judicial. Na ocasião, em que o seu voto foi vencido por todos os outros Ministros da Terceira Turma, a Ministra Nancy Andrighi fundamentou sua posição no Enunciado nº 198, aprovado na III Jornada de Direito Civil realizada pelo Centro de Estudos Judiciários do Conselho da Justiça Federal $^{17}$, no argumento de que o produtor rural prescinde de inscrição para ser qualificado como empresário e na defesa da natureza declaratória do registro ${ }^{18}$.

Nota-se, contudo, que, na ocasião, a Terceira Turma do Superior Tribunal de Justiça não adentrou na discussão quanto à necessidade de a inscrição no Registro Público de Empresas Mercantis ter sido efetuada há mais de dois anos pelo empresário rural, consignando, tão somente, a exigência de que o produtor rural deve estar registrado na ocasião do pedido e que a jurisprudência jamais havia dispensado a inscrição para o pedido de recuperação judicial ${ }^{19}$.

${ }^{17}$ CENTRO DE ESTUDOS JUDICIÁRIOS DO CONSELHO DA JUSTIÇA FEDERAL. III Jornada de Direito Civil. Enunciado n ${ }^{\circ}$ 198. Brasília/DF, 2005. Disponível em: https://www.cjf.jus.br/cjf/corregedoria-da-justica-federal/centro-de-estudos-judiciarios-1/publicacoes-1/cjf/corregedoria-da-justica-federal/centro-de-estudos-judiciarios-1/publicacoes-1/jornadas-cej/iii-jornada-de-direito-civil-1.pdf. Acesso em: 28 mar. 2019.

18 Veja-se trecho do voto da Ministra Nancy Andrighi no julgamento do REsp n 1.193.115/MT. "A Lei 11.101/05, conforme estabelecido em seu art. $1^{o}$, "disciplina a recuperação judicial, a recuperação extrajudicial e a falência do empresário e da sociedade empresária", remetendo seu intérprete, assim, ao conceito legal contido no art. 966 do CC. Segundo se infere dessa norma, empresário é a pessoa, física ou jurídica, que exerce de forma habitual e organizada atividade econômica voltada à produção ou à circulação de bens ou de serviços. Nessa medida, quem se dedica ao exercício profissional de atividade econômica organizada, ainda que de natureza agrícola ou pecuária, produzindo ou promovendo a circulação de bens ou serviços, deve ser considerado empresário. É importante destacar que - ao contrário do que ocorre com o empresário mercantil (art. 967 do CC) - o empresário cuja atividade rural constitua sua principal profissão não está obrigado a inscrever-se no Registro Público de Empresas Mercantis, segundo texto expresso do art. 971 do CC. Ademais, ainda que a lei exija do empresário, como regra, inscrição no Registro de Empresas, convém ressaltar que sua qualidade jurídica não é conferida pelo registro, mas sim pelo efetivo exercício da atividade profissional. Não por outro motivo, entende-se que a natureza jurídica desse registro é declaratória, e não constitutiva. A respeito do tema, revela-se oportuna a leitura do enunciado $n$. 198, aprovado na III Jornada de Direito Civil realizada pelo Centro de Estudos Judiciários do Conselho da Justiça Federal (cujas conclusões servem como orientação legítima para interpretação do Código Civil): A inscrição do empresário na Junta Comercial não é requisito para a sua caracterização, admitindo-se o exercício da empresa sem tal providência. $O$ empresário irregular reúne os requisitos do art. 966, sujeitando-se às normas do Código Civil e da legislação comercial, salvo naquilo em que forem incompatíveis com a sua condição ou diante de expressa disposição em contrário. Avançando na análise da questão posta a desate, vale frisar que a Lei de Falência e Recuperação de Empresas exclui expressamente de seu âmbito de incidência, a teor do art. $2^{\circ}$, somente as empresas públicas, sociedades de economia mista, instituições financeiras, de consórcios, seguradoras e outras a elas equiparadas. Sua aplicabilidade, portanto, salvo essas exceções, destina-se à generalidade de pessoas físicas e jurídicas que ostentam a qualidade de empresário $\left(\right.$ art. $1^{\circ}$ ). Sob distinto norte, contudo, não se desconhece que a norma do art. 48, caput, da LFRE estipula que apenas "poderá requerer recuperação judicial o devedor que, no momento do pedido, exerça regularmente suas atividades há mais de 2 (dois) anos". É certo, por um lado, que, em regra, a regularidade de exercício da atividade empresarial é condição que pressupõe, para sua configuração, a efetiva inscrição no Registro Público de Empresas Mercantis. Por outro lado, todavia, há de se considerar, como já mencionado, que a inscrição do empresário rural no Registro de Empresas não é obrigatória, de modo que o exercício de suas atividades não pode ser tido por irregular em virtude, unicamente, da inexistência de registro. Ao lidar com a matéria, deve-se atentar, igualmente, à necessidade imposta pelo art. 970 do CC de se dispensar, no que concerne ao registro e seus efeitos, tratamento diferenciado e simplificado ao empresário rural, de modo a facilitar a continuidade e a manutenção de suas atividades". BRASIL. Superior Tribunal De Justiça. REsp no 1.193.115/MT. Terceira Turma. Relatora Ministra Nancy Andrighi, Relator p/ Acórdão Ministro Sidnei Beneti. Trecho do voto da Ministra Nancy Andrighi. Data de Julgamento: 20/08/2013. Data de Publicação: 07/10/2013. Grifos originais.

19 Veja-se trecho do voto do Ministro Sidnei Benetti, Relator p/ Acórdão, no julgamento do REsp n ${ }^{\circ}$ 1.193.115/MT “A jurisprudência, é certo, já dispensou a exigência de comprovação documental, inscrição na Junta Comercial durante todo o período mínimo de dois anos, mas jamais dispensou a exigência legal de comprovação da documental 
Nesse mesmo sentido, defendendo a exigência de inscrição prévia ao pedido de recuperação judicial, Ivo Waisberg, por exemplo, afirma que o art. 51, inc. V, da Lei n ${ }^{\circ} 11.101 / 2005$ é claro ao exigir que qualquer empresário possua registro no momento do pedido da recuperação judicial $^{20}$.

A controvérsia, portanto, cinge-se quanto à possibilidade de o empresário rural pessoa física, inscrito há menos de dois anos no Registro Público de Empresas Mercantis, ajuizar e ter deferido o pedido de recuperação judicial. Isso porque, conforme a exigência do art. 48, caput, da Lei n ${ }^{\circ} 11.101 / 2005$, na ocasião do pedido, o devedor deverá ter exercido atividade regular por mais de dois anos, lembrando-se que, para o empresário rural pessoa jurídica, há previsão expressa, no art. $48, \S 2^{\circ}$, da Lei $n^{\circ} 11.101 / 2005$, de que o exercício de atividade por esse período poderá ser comprovado por meio da DIPJ que tenha sido entregue tempestivamente.

No âmbito da jurisprudência, percebe-se que há tribunais pátrios que entendem que se faz necessária a inscrição do empresário rural para ser aferida a regularidade de sua atividade, enquanto outros tribunais entendem que o exercício regular da atividade prescinde de inscrição do empresário no Registro Público de Empresas Mercantis.

O Tribunal de Justiça do Estado do Mato Grosso (TJ/MT), por exemplo, possui sólida jurisprudência ${ }^{21.22}$ no sentido de exigir do empresário rural a inscrição por período superior a dois anos para o ajuizamento do pedido de recuperação judicial.

da condição de comerciante, documento esse que constitui documento substancial que necessariamente deve vir com a petição inicial ou no prazo de aditamento da inicial (CPC, art. 284). Com efeito, apenas se admitiu, como noticiado em nota do repertório de THEOTÔNIO NEGRÃO, JOSÉ ROBERTO G. GOUVÊA, LUÍS GUILHERME A. BONDIOLO e JOÃO FRANCISCO N. DA FONSECA ("CPC”, S. Paulo, Saraiva, 45 a ed., 2013, p. 1523, nota $1^{a}$ ao art. 48 da Lei 11.101/2005) que "o requisito "exercício regular das atividades empresariais há mais de dois anos no momento do pedido de recuperação judicial" não exige inscrição na Junta Comercial por tal período mínimo. Integrando a requerente da recuperação judicial grupo econômico existente há 15 anos, e sendo constituída há menos de dois anos mediante transferência de ativos das empresas do grupo para prosseguir no exercício de atividade já exercida por tais empresas, é de se ter como atendido o pressuposto do biênio mínimo de atividade empresarial no momento do pedido" (JTJ 336/644: AI 604.160-4/8-00). De qualquer forma, a inscrição no registro de comércio exige-se, necessariamente, antes do ajuizamento do pedido de recuperação judicial, não havendo como suprir-se pela inscrição posterior, como no caso, em que, como constante do Acórdão recorrido, veio, essa inscrição, a dar-se 55 dias após o ingresso do pedido de recuperação em Juízo". Brasil. Superior Tribunal de Justiça. REsp no 1.193.115/MT. Terceira Turma. Relatora Ministra Nancy Andrighi, Relator p/ Acórdão Ministro Sidnei Beneti. Trecho do voto do Ministro Sidnei Benetti. Data de Julgamento: 20/08/2013. Data de Publicação: 07/ $10 / 2013$.

${ }^{20}$ WAISBERG, Ivo. A Viabilidade da Recuperação Judicial do Produtor Rural. Revista do Advogado. Ano XXXVI, out./2016, n. 131, pp. 83-90, 2016, p. 88.

${ }^{21}$ AGRAVO DE INSTRUMENTO - RECUPERAÇÃO JUDICIAL - EMPRESÁRIOS RURAIS - EXCLUSÃO DA RECUPERAÇÃO - NÃO PREENCHIMENTO DOS REQUISITOS - SUSPENSÃO DAS INSCRIÇÕES NOS ÓRGÃOS DE INADIMPLÊNCIA E PROTESTO - IMPOSSIBILIDADE - HONORÁRIOS DO ADMINISTRADOR JUDICIAL - FIXADOS MODERADAMENTE - RECURSO DESPROVIDO. Para requerer a recuperação judicial é necessária a comprovação da inscrição no registro de comércio há pelo menos 02 (dois) anos antes do ajuizamento do pedido de recuperação judicial, a exegese dos artigos 48 e 51 ambos da Lei Federal n. 11.101/2005. [...]. MATO GROSSO. Tribunal de Justiça do Estado do Mato Grosso. Agravo de Instrumento $n^{\circ}$ 0074859-48.2016.8.11.0000. Quinta Câmara Cível. Relatora Desembargadora Cleuci Terezinha Chagas Pereira da Silva. Data de Julgamento: 07/12/2016. Data de Publicação: 13/12/2016. Grifou-se.

${ }^{22}$ RECURSO DE AGRAVO REGIMENTAL OU INTERNO (ART. 1.021, DO NCPC) - RECUPERAÇÃO JUDICIAL - EMPRESÁRIO RURAL - COMPROVAÇÃO DE PRÉVIA INSCRIÇÃO NA JUNTA COMERCIAL POR MAIS DE DOIS ANOS - NECESSIDADE - CARÁTER CONSTITUTIVO DA CONDIÇÃO DE EMPRESÁRIO - PRECEDENTE STJ - RAZÕES QUE NÃO INFIRMAM OS FUNDAMENTOS DA DECISÃO AGRAVADA - RECURSO DESPROVIDO. Se as razões do agravo regimental ou interno (art. 1.021, do NCPC) não infirmam os fundamentos da decisão agravada, de rigor o desprovimento do recurso. Conforme já decidiu o STJ, para o processamento de pedido de recuperação judicial de empresário rural, a prévia inscrição na Junta Comercial é indispensável, dada sua natureza constitutiva da condição de empresário. MATO GROSSO. Tribunal de Justiça do Estado do Mato Grosso. Agravo Regimental nº 0094921-12.2016.8.11.0000. Primeira Câmara Cível. 
A recuperação judicial do empresário rural pessoa física: necessidade de prazo mínimo de inscrição no registro público de empresas mercantis

No julgamento do Agravo de Instrumento de $n^{\circ}$ 0074859-48.2016.8.11.0000, a Desembargadora Cleuci Terezinha Chagas Pereira da Silva, do TJ/MT, em seu voto, destacou, após fazer referência aos arts. 48, caput, e 51, inc. V, ambos da Lei ${ }^{\circ} 11.101 / 2005$, e ao art. 971 do CC/2002, que os produtores rurais estão excluídos da recuperação judicial se seu registro na Junta Comercial não contar com pelo menos dois anos, ainda que desempenhem suas atividades econômicas há mais tempo, porquanto tal registro seria indispensável para a caracterização da sua condição de empresário.

No mesmo sentido, precedentes mais recentes do Tribunal de Justiça do Estado da Bahia $(\mathrm{TJ} / \mathrm{BA})^{23}$, superando o entendimento até então dominante de que a comprovação do exercício regular da atividade empresária pelo empresário rural prescindiria da inscrição no Registro Público de Empresas Mercantis ${ }^{24}$.

No julgamento do Agravo de Instrumento de $n^{\circ}$ 016232537.2016.8.05.0909, os Desembargadores do TJ/BA demonstraram preocupação quanto à utilização da recuperação judicial por empresários recém inscritos no Registro Público de Empresas Mercantis, notadamente quanto ao empresário ter contraído dívidas enquanto pessoa física para, logo em seguida, registrar-se e

Relatora Desembaradora Nilza Maria Pôssas de Carvalho. Data de Julgamento: 08/11/2016. Data de Publicação: 14/11/2016. Grifou-se.

${ }^{23}$ AGRAVO DE INSTRUMENTO. RECUPERAÇÃO JUDICIAL. PRODUTOR RURAL. DESCUMPRIMENTO DO REQUISITO TEMPORAL INSERIDO NO ART. 48, CAPUT, DA LEI DE FALÊNCIA. NATUREZA CONSTITUTIVA, E NÃO DECLARATÓRIA, DO REGISTRO NA JUNTA COMERCIAL. PREJUÍZO AOS CREDORES. VIOLAÇÃO AO PRINCÍPIO DA SEGURANÇA JURÍDICA. GRUPO ECONÔMICO DE FATO. INEXISTÊNCIA. 1. A exigência do art. 48, caput, da Lei de Falência, referente ao exercício regular das atividades empresariais por, no mínimo 2 (dois) anos, não constitui mera formalidade, possível de ser relevada pelo julgador em nome da função social da empresa, da conservação dos empregos e da retomada do crescimento econômico do país; pelo contrário, a exigência temporal destina-se a evitar a utilização abusiva da recuperação judicial e assegurar que importante instituto não seja utilizada de má-fé, com o mero intuito de frustrar a satisfação dos direitos dos credores, o que traria prejuízos não só para estes, como também para toda a sociedade. 2. Para o produtor rural, o registro na Junta Comercial tem natureza constitutiva, e não declaratória, razão pela qual aquele que deixar de realizá-lo não será considerado empresário e permanecerá regido pelas regras do direito civil, sendolhe vedada a aplicação dos institutos previstos na Lei de Falência, inclusive a recuperação judicial. Enunciados 201 e 202, da III Jornada de Direito Civil. Precedentes do STJ. 3. Haveria clara violação ao princípio da segurança jurídica se o produtor rural pudesse celebrar contratos e contrair dívidas como pessoa física, para, logo em seguida, tornar-se empresário individual e buscar a aplicação dos benefícios previstos na Lei de Falência, obstando, assim, as ações individuais de execução ajuizadas por seus credores. 4 . Na hipótese, descabe o pedido de recuperação judicial realizado pelos agravados Heinz Kudiess e Jerusa Gambatto Kudiess, por duas razões: em primeiro lugar, porque não atendem ao requisito do art. 48, caput, da Lei de Falência, isto é, no momento do pedido, não exerciam atividades como empresários há mais de 2 (dois) anos, mas tão somente há três meses; em segundo lugar, porque o registro na JUCEB teve o único e exclusivo intuito de viabilizar o pedido de recuperação judicial, e, assim, frustrar a satisfação do crédito milionário de seus credores, inclusive a ora agravante. Agravo de instrumento conhecido e provido por maioria. BAHIA. Tribunal de Justiça do Estado da Bahia. Agravo de Instrumento de $n^{\circ}$ 016232537.2016.8.05.0909. Terceira Câmara Cível. Relator Desembargador Ivanilton Santos da Silva. Data de Publicação: 04/04/2018. Grifou-se.

${ }^{24}$ PROCESSO CIVIL. AGRAVO DE INSTRUMENTO. PROCESSAMENTO DE RECUPERAÇÃO JUDICIAL. ATIVIDADE RURAL. REGULARIDADE DA ATIVIDADE EMPRESARIAL. BIÊNIO QUE PODE SER AFERIDO COM A SIMPLES MANUTENÇÃO E CONTINUIDADE DO EXERCÍCIO DA ATIVIDADE. RECURSO CONHECIDO E NÃO PROVIDO. O deferimento da recuperação judicial pressupõe a comprovação documental da qualidade de empresário e a regularidade da atividade empresarial pelo biênio mínimo estabelecido na legislação de regência, devendo ser aferida pela constatação da manutenção e continuidade do próprio exercício da atividade. Precedentes do Superior Tribunal de Justiça (REsp 1193115/MT). In casu, apesar dos agravados não possuírem dois anos de inscrição na Junta Comercial, o fizeram antes do ajuizamento da ação e comprovaram exercer a atividade rural por período superior ao biênio previsto em lei, inexistindo óbice ao processamento da recuperação judicial. BAHIA. Tribunal de Justiça do Estado da Bahia. Agravo de Instrumento $\mathrm{n}^{\circ}$ 001339758.2016.8.05.0000. Primeira Câmara Cível. Relator Desembargador Mário Augusto Albiani Alves Junior. Data de Publicação: 09/03/2017. Grifou-se. 
ajuizar o pedido de recuperação judicial, submetendo aos efeitos do processo o passivo adquirido quando pessoa física.

No mesmo sentido, Raquel Stajzn afirma que o prazo de dois anos de regular exercício da atividade, demonstrado mediante a apresentação de certidão da inscrição no Registro Público de Empresas Mercantis, tem como função justamente "evitar oportunismos, isto é, a obtenção de vantagem ou beneficio por quem, aventurando-se e assumindo riscos, exercesse atividade econômica sem, para tanto, estar devidamente matriculado, na forma do previsto no Código Civil para qualquer empresário, pessoa natural ou jurídica ${ }^{, 25}$.

Nelson Abrão, comentando o tema ainda na vigência do Decreto-Lei n ${ }^{\circ} 7.661 / 1945$, sustentava a necessidade de se aferir a regularidade da atividade empresária por dois anos a partir da inscrição do empresário no Registro Público de Empresas Mercantis, sob a justificativa de que, sem a exigência do registro por esse período, "surgiriam da noite para o dia, como cogumelos, aqueles que se estabeleceram na véspera para, no dia seguinte, sob o beneplácito da lei, propor a liquidar os seus débitos na base de cinquenta por cento"26.

Em parecer jurídico sobre a matéria acostado às fls. 482/502 do Agravo de Instrumento de $n^{\circ}$ 2005580-50.2018.8.26.0000, em trâmite perante o Tribunal de Justiça do Estado de São Paulo, Alfredo de Assis Gonçalves Neto ${ }^{27}$ também ressalta o propósito do disposto no art. 48, caput, da Lei $\mathrm{n}^{\mathbf{0}} 11.101 / 2005$, qual seja de impedir que seja criado um entre com a finalidade precípua de angariar recursos e assumir débitos para, por meio da recuperação judicial, saldá-los legalmente com abatimento ou dilação de prazo excepcionais.

Contudo, ao comparar a disposição do art. 48, caput, da Lei no 11.101/2005, que prevê a necessidade de o devedor "exercer regularmente suas atividades", com o art. 158, inc. I, do Decreto-Lei no 7.661/1945, que previa a necessidade de o devedor "exercer regularmente o comércio", Alfredo de Assis Gonçalves Neto ${ }^{28}$ destaca que a nova legislação expandiu o alcance da anterior, pois não impõe que as atividades tenham tido natureza empresarial por todo o biênio. Assim, consigna o autor que "um agricultor não optante pela inscrição no Registro Público de Empresas Mercantis pode somar o seu período de exploração da terra com o que lhe sobrevier a partir do momento em que fizer essa inscrição" ${ }^{29}$. Sobre o argumento contrário de que, em virtude de a inscrição, para o empresário rural, ter natureza constitutiva da condição de empresário, não seria possível o pedido de recuperação judicial por produtor com menos de dois anos de registro, o autor ainda destaca:

Pode-se argumentar que, em se tratando de produtor rural, sua inscrição nesse regis-
tro é constitutiva da qualidade de empresário e, por isso, não seria possível fazer tal
paralelo. Ocorre que o fato de a inscrição outorgar ao ruralista a qualidade de empre-
sário não significa apagar o seu passado; trata-se de simples mudança de um regime

${ }^{25}$ STAJN, Raquel. Comentários ao art. 48. In: SOUSA JR., Francisco Satiro de; PITOMBO, Antônio S. A. de M. (Coord.). Comentários à Lei de Recuperações e Falência. $2^{a}$ ed. São Paulo: RT, 2007, p. 225.

${ }^{26}$ ABRÃO, Nelson. Curso de Direito Falimentar. São Paulo: Editora Saraiva, 1978, p. 191.

${ }^{27}$ GONÇALVES NETO, Alfredo de Assis. Parecer jurídico juntado às fls. 482/502 dos autos do Agravo de Instrumento n 2005580-50.2018.8.26.0000, interposto por “Tangará Importadora e Exportadora S/A” em face de “José Serra Netto - ME”, em trâmite junto à $1^{\text {a }}$ Câmara Reservada de Direito Empresarial do Tribunal de Justiça do Estado de São Paulo, mediante consulta do advogado Ivo Waisberg. Curitiba/PR. Assinado em: 30 jun. 2016. Fl. 496 dos autos.

${ }^{28}$ GONÇALVES NETO, Alfredo de Assis. Parecer jurídico juntado às fls. 482/502 dos autos do Agravo de Instrumento n $2005580-50.2018 .8 .26 .0000$, interposto por “Tangará Importadora e Exportadora S/A” em face de “José Serra Netto - ME”, em trâmite junto à $1^{\text {a }}$ Câmara Reservada de Direito Empresarial do Tribunal de Justiça do Estado de São Paulo, mediante consulta do advogado Ivo Waisberg. Curitiba/PR. Assinado em: 30 jun. 2016. Fl. 496 dos autos.

${ }^{29}$ GONÇALVES NETO, Alfredo de Assis. Parecer jurídico juntado às fls. 482/502 dos autos do Agravo de Instrumento n 2005580-50.2018.8.26.0000, interposto por “Tangará Importadora e Exportadora S/A" em face de "José Serra Netto - ME”, em trâmite junto à $1^{\text {a }}$ Câmara Reservada de Direito Empresarial do Tribunal de Justiça do Estado de São Paulo, mediante consulta do advogado Ivo Waisberg. Curitiba/PR. Assinado em: 30 jun. 2016. Fl. 496 dos autos. 
A recuperação judicial do empresário rural pessoa física: necessidade de prazo mínimo de inscrição no registro público de empresas mercantis

jurídico para outro. Se ele estava a exercer a atividade agrícola por tempo anterior a essa inscrição (sem registro algum, porque disso não dependia), contraiu obrigações e teve direitos que marcaram seu comportamento e que, de algum modo, poderiam ter contribuído para seu infortúnio financeiro. Ao se inscrever como empresário, o ruralista traz consigo todos esses direitos e obrigações oriundos de sua atividade rural anterior, que prossegue igual no novo regime. Negar essa evidência seria como impedir que uma sociedade empresária resultante da fusão de duas outras, computasse, no biênio exigido para requerer sua recuperação judicial os negócios havidos pelas fusionadas antes do seu nascimento. E o que dizer da sociedade resultante da cisão de outra já existente? Não há quem afaste, por esse motivo, o direito de essas sociedades novas pleitearem recuperação judicial pela soma temporal das atividades que assumiram, ocorridas antes de terem obtido a inscrição no Registro Público de Empresas Mercantis ${ }^{30}$.

No mesmo sentido, Manoel Justino Bezerra Filho ${ }^{31}$ também defende a possibilidade, para a contagem do biênio exigido, que se some, ao período em que o empresário rural exerceu atividade empresária com registro arquivado, o tempo pelo qual o produtor desempenhou atividade sem inscrição. Defende o autor que a intenção do dispositivo é impedir que empresários com inabilidade acentuada, de tal forma que, em tão pouco tempo se chegue a uma situação de crise, tenham acesso ao instituto. Assim, para o empresário rural que exerce atividade há mais de dois anos, mesmo sem possuir inscrição por tal período, a lógica do impedimento não seria aplicável, pois o produtor comprova, com o exercício da atividade por tempo superior ao exigido, que não ostenta a inabilidade acentuada a qual o caput do art. 48 da Lei $\mathrm{n}^{\circ} 11.101 / 2005$ visa a coibir.

Nessa linha de pensamento, o Tribunal de Justiça do Estado de São Paulo possui diversos precedentes recentes ${ }^{32-33-34}$, em que se destaca, notadamente, a mera exigência de exercício de

${ }^{30}$ GONÇALVES NETO, Alfredo de Assis. Parecer jurídico juntado às fls. 482/502 dos autos do Agravo de Instrumento $\mathrm{n}^{\circ}$ 2005580-50.2018.8.26.0000, interposto por “Tangará Importadora e Exportadora S/A” em face de “José Serra Netto

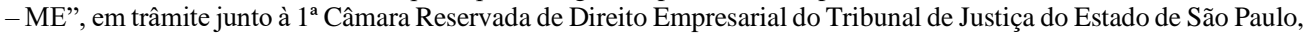
mediante consulta do advogado Ivo Waisberg. Curitiba/PR. Assinado em: 30 jun. 2016. Fl. 497 dos autos.

${ }^{31}$ BEZERRA FILHO, Manoel Justino. Lei de Recuperação de Empresas e Falência: Lei 11.101/2005. Comentada artigo por artigo. 11. ed. São Paulo: Revista dos Tribunais, 2016, p. 157.

32 Agravo de instrumento. Decisão que deferiu o processamento da recuperação judicial dos agravados. Competência para o decreto de falência. Juízo do local do principal estabelecimento do devedor. Inteligência do art. $3^{\circ}$ da Lei $\mathrm{n}$. 11.101/05. Recuperação judicial de empresários produtores rurais. Natureza declaratória do registro dos produtores rurais na JUCESP reconhecida. Art. 971 do CC. Aplicação da teoria da empresa. Conceito jurídico de empresário determinado pelo efetivo exercício de atividade econômica organizada para a produção ou circulação de bens ou serviços, nos termos do art. 966, caput, do CC. Art. 48, caput, da LRF que apenas exige que o empresário que pleiteia a recuperação judicial exerça suas atividades há mais de dois anos, nada dispondo sobre a necessidade de registro na Junta Comercial por igual período. Processamento da recuperação que depende apenas da verificação formal dos requisitos objetivos dos arts. 48 e 51 da LRF. [...]. Recurso improvido. SÃO PAULO. Tribunal de Justiça do Estado de São Paulo. Agravo de Instrumento no 2152473-10.2018.8.26.0000. 1 ${ }^{\text {a }}$ Câmara Reservada de Direito Empresarial. Relator Desembargador Hamid Bdine. Data de Publicação: 09/11/2018. Grifou-se.

33 "É certo que o registro mercantil só veio em setembro de 2.016, mas o que importa é que tenha sido feito antes do pedido recuperacional, que só foi distribuído no mês seguinte. Assim, não é difícil concluir que, se, para os empresários em geral, exige-se registro mercantil antecedente de dois anos para que possa requerer a recuperação judicial ou extrajudicial; o mesmo não sucede com os empresários rurais porque, para eles, o registro na Junta Comercial é facultativo. Exige-se, é certo, que o façam para deduzir o requerimento, mas estão dispensados de comprová-lo pelos dois anos antecedentes, bastando que comprovem o exercício da atividade por tal lapso de tempo". SÃO PAULO. Tribunal de Justiça do Estado de São Paulo. Agravo de Instrumento no 2048349-10.2017.8.26.0000. 2a Câmara Reservada de Direito Empresarial. Trecho do voto do Exmo. Relator Desembargador José Araldo da Costa Telles. Data de Julgamento: 30/10/2017. Grifou-se.

${ }^{34}$ Recuperação judicial. Requerimento por produtores rurais em atividade por prazo superior àquele de 2 (dois) anos exigido pelo artigo 48, caput, da Lei $\mathrm{n}^{\circ}$ 11.101/2005, integrantes de grupo econômico na condição de empresários individuais respaldados pelos artigos 966 e 971 do Código Civil e/ou de sócios das sociedades coautoras. Legitimidade reconhecida. Irrelevância da alegada proximidade entre as datas de ajuizamento do feito e das prévias inscrições dos produtores rurais como empresários individuais na Junta Comercial do Estado de São Paulo. Firme entendimento jurisprudencial no sentido de que a regularidade da atividade empresarial pelo biênio mínimo estabelecido no supramencionado dispositivo legal deve ser aferida pela constatação da manutenção e continuidade 
atividade por período superior a dois anos, não havendo disposição legal que obrigue o registro do empresário por igual período, bem como a natureza declaratória do registro do empresário rural, que exerceria atividade regularmente mesmo não possuindo inscrição no Registro Público de Empresas Mercantis.

Outro fundamento, utilizado pelo Desembargador Alexandre Lazzarini no julgamento do Agravo de Instrumento de $\mathrm{n}^{\mathrm{o}}$ 2005580-50.2018.8.26.0000, consiste na faculdade conferida aos empresários rurais pessoas jurídicas para que comprovem a regularidade de suas atividades por mais de dois anos por meio da apresentação da DIPJ, atual Escrituração Contábil Fiscal (ECF), que tenha sido entregue tempestivamente, de modo que não faria sentido dispensar tratamento mais rígido aos empresários rurais pessoas físicas, que não prestam as informações por meio do ECF:

\begin{abstract}
"Destaca-se, de início, que os agravados, produtores rurais, realizaram seus registros perante a Junta Comercial antes do pedido de recuperação judicial.

Todavia, a credora agravante alega que esse registro deveria ter sido realizado há, pelo menos, 2 anos, para que pudesse ser requerida a recuperação judicial, conforme art. 48, caput, da Lei $\mathrm{n}^{\circ}$ 11.101/05 ("Poderá requerer recuperação judicial o devedor que, no momento do pedido, exerça regularmente suas atividades há mais de 2 anos e que atenda aos seguintes requisitos cumulativamente...").

Tal alegação, contudo, não deve ser acolhida, pois, conforme o $\$ 2^{\circ}$ do art. 48 , da Lei $\mathrm{n}^{\circ} 11.101 / 05$, introduzido pela Lei $\mathrm{n}^{\circ} 12.873$ em 2013, "tratando-se de exercício de atividade rural por pessoa jurídica, admite-se a comprovação do prazo estabelecido no caput deste artigo por meio da Declaração de Informações Econômico-Fiscais da Pessoa Jurídica DIPJ que tenha sido entregue tempestivamente".

Entende-se, daí, que não é necessária a inscrição na Junta Comercial há pelo menos 2 anos para que o empresário produtor rural possa requerer a recuperação judicial, pois pode fazer prova do exercício da atividade rural por outro meio, que não a inscrição de seus atos constitutivos na Junta Comercial”. SÃO PAULO. Tribunal de Justiça do Estado de São Paulo. Agravo de Instrumento $\mathrm{n}^{\circ}$ 200558050.2018.8.26.0000. $1^{\text {a }}$ Câmara Reservada de Direito Empresarial. Trecho do voto do Exmo. Relator Desembargador Alexandre Lazzarini. Data de Julgamento: 09/05/ 2018.
\end{abstract}

Sobre este ponto, Alfredo de Assis Gonçalves Neto ${ }^{35}$ ainda afirma que seria teratológica qualquer interpretação restritiva, que não conferisse o mesmo tratamento ao empresário rural pessoa física e às demais entidades excluídas da elaboração desse documento fiscal. Sustenta o autor que, para o empresário rural pessoa física, bastaria a comprovação por meio adequado que deixe inequívoca a regularidade do exercício de suas atividades por mais de dois anos.

Acompanhando o entendimento do TJ/SP, o Tribunal de Justiça do Estado do Rio de Janeiro $(\mathrm{TJ} / \mathrm{RJ})^{36}$ também possui recente precedente, firmado com o julgamento do Mandado de

de seu exercício, e não a partir da prova da existência de registro do empresário ou ente empresarial por aquele lapso temporal. Manutenção do deferimento do processamento da demanda. Agravo de instrumento desprovido". SÃO PAULO. Tribunal de Justiça do Estado de São Paulo. Agravo de Instrumento no 2037064-59.2013.8.26.0000. $2^{\mathrm{a}}$ Câmara Reservada de Direito Empresarial. Relator Desembargador José Reynaldo. Data de Julgamento: 22/09/2014. Grifou-se.

${ }^{35}$ GONÇALVES NETO, Alfredo de Assis. Parecer jurídico juntado às fls. 482/502 dos autos do Agravo de Instrumento n 2005580-50.2018.8.26.0000, interposto por “Tangará Importadora e Exportadora S/A” em face de “José Serra Netto - ME”, em trâmite junto à $1^{\text {a }}$ Câmara Reservada de Direito Empresarial do Tribunal de Justiça do Estado de São Paulo, mediante consulta do advogado Ivo Waisberg. Curitiba/PR. Assinado em: 30 jun. 2016. Fls. 499-499 dos autos.

${ }^{36}$ Mandado de Segurança com pedido de liminar. Direito Empresarial. Sociedade empresária e Empresário, em processo de recuperação judicial. Inconformismo manifestado por instituição financeira credora com a decisão pela qual o juízo singular deferiu o processamento da recuperação judicial do empresário, que apesar de exercer a atividade rural há mais de dois anos, fez sua inscrição na Junta Comercial há menos de dois anos. [...]. Previsão do 
A recuperação judicial do empresário rural pessoa física: necessidade de prazo mínimo de inscrição no registro público de empresas mercantis

Segurança nº 0019729-80.2018.8.19.0000 pela Vigésima Segunda Câmara Cível daquele Tribunal, facultando ao empresário rural inscrito há menos de dois anos no Registro Público de Empresas Mercantis, mas que exerça atividade por período superior a dois anos, o acesso ao instituto da recuperação judicial.

No voto que foi acompanhado por todos os demais desembargadores da Câmara, o Desembargador Carlos Eduardo Moreira da Silva destacou a facultatividade da inscrição do empresário rural no Registro Público de Empresas Mercantis, a inexistência de norma expressa que obrigue o exercício da atividade empresária mediante registro há mais de dois anos, de modo que a regularidade da atividade seria aferida pelo "exercício da atividade profissional”, e a possibilidade de se comprovar a regularidade mediante outro meio de prova diverso do registro ${ }^{37}$.

No âmbito do Superior Tribunal de Justiça (STJ), ainda não há posicionamento definitivo sobre a matéria, salvo decisões monocráticas isoladas ${ }^{38}$.

Código Civil no sentido da facultatividade de inscrição do produtor rural no órgão do Registro de Comércio. Existência de entendimento doutrinário e jurisprudencial no sentido de que ao produtor rural deve ser deferida a recuperação judicial, desde que comprove o exercício de atividade econômica por, no mínimo, dois anos, ainda que o seu registro na junta comercial tenha ocorrido há menos tempo. Inteligência do art. $48, \S 2^{\circ}$, da Lei $\mathrm{n}^{\circ}$ 11.101/05: "tratando-se de exercício de atividade rural por pessoa jurídica, admite-se a comprovação do prazo estabelecido no caput deste artigo por meio da Declaração de Informações Econômico-Fiscais da Pessoa Jurídica DIPJ que tenha sido entregue tempestivamente." Admissão pela Lei de Recuperação e Falência de que se prove o exercício da atividade rural por outro meio, que não a inscrição dos atos constitutivos na Junta Comercial. Jurisprudência das Câmaras Reservadas de Direito Empresarial do TJ/SP. Ainda que a questão ainda não tenha sido pacificada pela jurisprudência, convém prestigiar o posicionamento mais liberal, que melhor se amolda ao princípio da preservação da empresa estampado na Lei $n^{\mathbf{0}} \mathbf{1 1 . 1 0 1}$, de 09/02/2005, concebida com o objetivo de prestigiar a classe empresarial, mediante o reconhecimento da função da propriedade e a função social da empresa, estabelecendo que " a recuperação judicial tem por objetivo viabilizar a superação da situação de crise econômica-financeira do devedor, a fim de permitir a manutenção da fonte produtora, do emprego dos trabalhadores e dos interesses dos credores, promovendo, assim, a preservação da empresa, sua função social e o estímulo à atividade econômica." (art. 47, da Lei $n^{\circ}$ 11.101, de 09/02/2005). Denegação da ordem. RIO DE JANEIRO. Tribunal de Justiça do Estado do Rio de Janeiro. Mandado de Segurança de nº 0019729-80.2018.8.19.0000. 22 ${ }^{\text {a }}$ Câmara Cível. Des. Relator Carlos Eduardo Moreira da Silva. Data de Julgamento: 06/11/2018. Grifou-se.

37 "No tocante ao argumento de que o empresário individual Juarez Quintão Hosken não teria preenchido requisito temporal de inscrição na Junta Comercial no mínimo por (02) dois anos, antes da formulação do pedido de recuperação judicial, verifico que não importa na nulidade da decisão impugnada, a uma, porque o Código Civil prevê a facultatividade de inscrição do produtor rural no órgão do Registro de Comércio e, a duas, em razão da existência de entendimento doutrinário e jurisprudencial no sentido de que ao produtor rural deve ser deferida a recuperação judicial, desde que comprove o exercício de atividade econômica por, no mínimo, dois anos, ainda que o seu registro na junta comercial tenha ocorrido há menos tempo. De acordo com previsão expressa do art. 971 do Código Civil, é necessário que o empresário que pleiteia a recuperação judicial exerça suas atividades há mais de dois anos, nada dispondo sobre a necessidade de registro na Junta Comercial por igual período, devendo, assim, ser considerado empresário pelo exercício da atividade profissional, e não pela inscrição perante o órgão competente. Referida linha de interpretação encontra amparo, também, no artigo do art. $48, \S 2^{\circ}$, da Lei $n^{\circ} 11.101 / 05$ : "tratando-se de exercício de atividade rural por pessoa jurídica, admite-se a comprovação do prazo estabelecido no caput deste artigo por meio da Declaração de Informações Econômico-Fiscais da Pessoa Jurídica DIPJ que tenha sido entregue tempestivamente." Portanto, a Lei de Recuperação e Falência admite a prova do exercício da atividade rural por outro meio, que não a inscrição dos atos constitutivos na Junta Comercial". RIO DE JANEIRO. Tribunal de Justiça do Estado do Rio de Janeiro. Mandado de Segurança de nº 0019729-80.2018.8.19.0000. 22a Câmara Cível. Des. Relator Carlos Eduardo Moreira da Silva. Trecho do voto do Desembargador Relator. Data de Julgamento: 06/11/2018.

38 "A inscrição no Registro Público de Empresas Mercantis não é condição imprescindível para a concessão do benefício da recuperação judicial a produtores rurais. Isso porque, apesar de a Lei 11.101/05, em seu art. 48, impor que o devedor, para se beneficiar da recuperação judicial, demonstre o exercício regular de suas atividades há mais de dois anos, o empresário rural, de acordo com o art. 971 do CC, não está obrigado a inscrever-se no Registro Público de Empresas Mercantis. Além disso, sabe-se que a qualidade jurídica de empresário não é conferida pelo registro, mas sim pelo efetivo exercício da atividade profissional, consoante o enunciado 98 da III Jornada de Direito Civil. Assim, como a inscrição do empresário rural no registro de empresas não é obrigatória, o exercício de suas atividades não pode ser tido por irregular em virtude, unicamente, da inexistência do registro. Acrescente-se ainda a necessidade de se dispensar tratamento diferenciado e simplificado ao empresário rural, de modo a facilitar a continuidade e a 
Registre-se, ainda, que, no STJ, houve a tentativa de afetação da matéria para o julgamento de Recursos Especiais no rito de recursos repetitivos, a qual, todavia, restou frustrada em virtude de a maioria dos Ministros ter entendido, no caso, que o tema ainda necessitaria ser objeto de discussões mais aprofundadas na instância superior antes de se chegar a um entendimento vinculante ${ }^{39}$.

\section{A RECUPERAÇÃO JUDICIAL DO EMPRESÁRIO RURAL PESSOA FÍSICA E OS PROJETOS DE LEI No 6.279/2013 E N 10.220/2018}

Por fim, vale destacar a existência do Projeto de Lei $n^{\circ} 6.279 / 2013^{40}$ e do Projeto de Lei $\mathrm{n}^{\circ} 10.220 / 2018^{41}$, os quais repercutem na disciplina da recuperação judicial do empresário rural.

Na justificativa do Projeto de Lei $n^{\circ}$ 6.279/2013, apresentado pelo Deputado Jerônimo Goergen, do Estado do Rio Grande do Sul, e que aguarda deliberação na Comissão de Constituição e Justiça e de Cidadania (CCJC), expõe o citado Deputado que haveria a necessidade de ser possibilitado o acesso do produtor rural, não inscrito no Registro Público de Empresas Mercantis, aos institutos da recuperação judicial e da recuperação extrajudicial ${ }^{42}$.

Todavia, ao invés de alterar o próprio art. $1^{\circ}$ da Lei $n^{\circ} 11.101 / 2005$, que trata dos legitimados a requererem recuperação judicial (empresário e sociedade empresária), para conferir segurança jurídica aos produtores rurais não registrados que desejem ingressar com pedido de recuperação judicial, ou mesmo aditar ou incluir uma exceção ao art. 51, inc. V, da Lei no 11.101/ 2005, que exige prova da inscrição perante o Registro Público de Empresas Mercantis, o Projeto de Lei ${ }^{\circ} 6.279 / 2013$ tão somente altera a redação do art. 48, parágrafo segundo, da Lei ${ }^{\circ} 11.101 /$

manutenção de suas atividades, conforme disposto no art. 970 do CC.”. BRASIL. Superior Tribunal de Justiça. AResp n 896.041/SP. (2016/0086265-2). Decisão Monocrática. Min. Relator: Marco Aurélio Belizze. Data de Publicação: $12 / 05 / 2016$.

${ }^{39}$ PROPOSTA DE AFETAÇÃO. RECURSO ESPECIAL REPETITIVO. ART. 1.036 E SEGUINTES DO CPC. ART. 257 RISTJ. DIREITO EMPRESARIAL. RECUPERAÇÃO JUDICIAL. EMPRESÁRIO INDIVIDUAL RURAL. INSCRIÇÃO A MENOS DE DOIS ANOS NO REGISTRO PÚBLICO DE EMPRESAS MERCANTIS. ART. 971 CÓDIGO CIVIL. ARTS. 48, CAPUT, E 51, V, LEI 11.101/2005. 1. A questão de direito que se pretende afetar ao rito dos recursos repetitivos consiste na possibilidade de o empresário individual rural (produtor rural) - pessoa física - requerer o benefício da recuperação judicial, ainda que não se tenha inscrito no Registro Público de Empresas Mercantis há mais de 2 (dois) anos da data do pedido (art. 971 do Código Civil c/c arts. 48, caput, e 51, V, da Lei n. 11.101/2005). 2. Embora de grande relevância para o país, esta Corte Superior não emitiu posicionamento fundamentado sobre o tema em destaque. 3. Diante da ausência de precedentes sobre a referida questão de direito e em homenagem ao princípio da segurança jurídica, deve-se aguardar, para fins de afetação ao rito previsto no art. 1.036 e seguintes do Código de Processo Civil, a formação de jurisprudência no Superior Tribunal de Justiça, orientação que vem sendo adotada pela Segunda Seção na afetação e análise de temas repetitivos. 4. Questão jurídica não afetada ao rito dos recursos repetitivos (art. 257-A, $\S 2^{\circ}$, RISTJ). BRASIL. Superior Tribunal de Justiça. ProAfR no REsp $\mathrm{n}^{\circ}$ 1.684.994/MT. 2017/0176137-8. Segunda Seção. Min. Relator: Luis Felipe Salomão. Data de Julgamento: 28/11/ 2017. Data de Publicação: 05/12/2017.

${ }^{40}$ BRASIL. Projeto de Lei $\mathbf{n}^{\mathbf{0}}$ 6.279, de 05 de setembro de 2013. Disponível em: https://www.camara.leg.br/proposicoesWeb/fichadetramitacao?idProposicao=590868. Acesso em: 29 mar. 2019.

${ }^{41}$ BRASIL. Projeto de Lei $\mathbf{n}^{\mathbf{0}} \mathbf{1 0 . 2 2 0}$, de 10 de maio de 2018. Disponível em: https://www.camara.leg.br/proposicoesWeb/fichadetramitacao?idProposicao=2174927. Acesso em: 31 mar. 2019.

42 "Por outro lado, o ingresso do produtor no regime jurídico empresarial - que lhe permitira a utilização da recuperação judicial na forma que hoje está inscrita na Lei 11.101-2005-facultado pelo art. 971, do Código Civil, além de não ter se popularizado entre os agricultores, condiciona a recuperação judicial ao registro prévio perante a Junta Comercial, pelo prazo de dois anos. Cria-se, pois uma lacuna na legislação brasileira, que não oferece mecanismos para a superação da crise do agricultor que não tenha optado pelo registro na Junta Comercial. Esta circunstância precisa ser corrigida mediante a viabilização da recuperação judicial, pelo procedimento regular ou mediante a apresentação do plano especial, e extrajudicial, como pretende o projeto ora apresentado". BRASIL. Projeto de Lei $\mathbf{n}^{0}$ 6.279, de 05 de setembro de 2013. Disponível em: https://www.camara.leg.br/proposicoesWeb/fichadetramitacao?idProposicao=590868. Acesso em: 29 mar. 2019. 
A recuperação judicial do empresário rural pessoa física: necessidade de prazo mínimo de inscrição no registro público de empresas mercantis

2005, para fazer constar que "[t]ratando-se de exercício de atividade rural, admite-se a comprovação do prazo estabelecido no caput deste artigo com a declaração de imposto de renda".

Pela questionável redação atual, ao invés de permitir o acesso à recuperação judicial ao empresário rural não inscrito no Registro Público de Empresas Mercantis - pois perduraria a exigência do art. 51, inc. V, da Lei ${ }^{\circ} 11.101 / 2005$-, o Projeto de Lei ${ }^{\circ}$ 6.279/2013 consistiria em mais um elemento a favor do empresário rural pessoa física em crise que tenha se registrado há menos de dois anos, mas que exerça atividade empresária por mais tempo, e que deseja ingressar com o pedido de recuperação judicial. Isso porque o exercício da atividade empresária, à época em que inexistente a inscrição, passaria a poder ser demonstrado com a Declaração de Imposto de Renda Pessoa Física (DIRPF) do produtor rural.

Dessa forma, entende-se que a atual redação do Projeto de Lei nº 6.279/2013 não atende aos fins declarados em sua justificativa - possibilitar a utilização da recuperação judicial e da recuperação extrajudicial pelo empresário rural não inscrito no Registro Público de Empresas Mercantis -, justamente porque permaneceria inalterada a exigência disposta no art. 51, inc. V, da Lei $n^{\circ} 11.101 / 2005$, qual seja a de o devedor apresentar certidão de regularidade naquele órgão.

Por seu turno, o Projeto de Lei ${ }^{\circ} 10.220 / 2018$, apresentado pelo Poder Executivo e que ainda se encontra em estágio inicial de tramitação, pretende 'modernizar o sistema recuperacional e falimentar brasileiro', alterando e incluindo, para tanto, diversos dispositivos na Lei $\mathrm{n}^{\circ}$ $11.101 / 2005$.

Antes do envio do referido Projeto de Lei ao Congresso Nacional, destaque-se que havia uma expectativa, pelo grupo de trabalho que inicialmente ficara encarregado de redigir a minuta do texto, de que o acesso ao instituto da recuperação judicial seria ampliado, dos "empresários" e das "sociedades empresárias", para todos os "agentes econômicos", o que permitiria o acesso dos produtores rurais, mesmo não inscritos no Registro Público de Empresas Mercantis, ao benefício legal ${ }^{43-44}$.

Na versão final do Projeto de Lei enviado ao Congresso Nacional, contudo, não constou a alteração anteriormente pensada, mantendo-se, portanto, o acesso à recuperação judicial aos empresários e às sociedades empresárias. Da mesma forma, permanecem as exigências dos arts. 48, caput, e 51, inc. V, ambos da Lei $\mathrm{n}^{\mathrm{o}} 11.101 / 2005$, referentes, respectivamente, ao exercício de atividade regular por mais de dois anos e à inscrição no Registro Público de Empresas Mercantis à data do pedido de recuperação judicial.

Apesar de inexistir qualquer alteração substancial à matéria aqui tratada pelo Projeto de Lei $\mathrm{n}^{\circ} 10.220 / 201$, registre-se a proposta de atualização à redação do art. 48, parágrafo segundo, da Lei $\mathrm{n}^{\circ} 11.101 / 2005$, o qual passaria a prever que "[n]a hipótese de exercício de atividade

\footnotetext{
${ }^{43}$ Veja-se trecho de matéria publicada no portal "Jota": "Primeiramente, o texto abrange o leque de empresas autorizadas a pleitear a recuperação judicial ao substituir na Lei os termos "empresário" e "sociedade empresária” por "agentes econômicos". Somente esta alteração irá permitir, por exemplo, que o produtor rural possa ser autor de um pedido de recuperação judicial, situação que há muito tempo vem sendo perseguida pelo agronegócio. A importância desta mudança tem caráter óbvio, uma vez que o setor sempre apresentou garantiu bons números à economia brasileira". NETTO, Ângelo Guerra. Aspectos da Reforma da Lei de Recuperação Judicial. Jota. Publicado em: 25 set. 2019. Disponível em: https://www.jota.info/opiniao-e-analise/artigos/aspectos-da-reforma-da-lei-de-recuperacao-judicial-25092017. Acesso em: 31 mar. 2019.

44 No mesmo sentido, veja-se matéria publicada por Renaldo Limiro, em sua coluna no portal Rota Jurídica: LIMIRO, Renaldo. Marcantes Alterações na Lei de Recuperação Judicial. Rota Jurídica. Publicado em: 16 out. 2017. Disponível em: https://www.rotajuridica.com.br/coluna_2/marcantes-alteracoes-na-lei-de-recuperacao-judicial/. Acesso em: 31 mar. 2019.
} 
rural por pessoa jurídica, admite-se a comprovação do prazo estabelecido no caput por meio da Escrituração Contábil Fiscal que tenha sido entregue tempestivamente".

Assim, o Projeto de Lei no 10.220/2018, em relação à recuperação judicial do empresário rural, tão somente substitui a faculdade de o empresário rural pessoa jurídica apresentar Declaração de Informações Econômico-fiscais da Pessoa Jurídica pela apresentação da Escrituração Contábil Fiscal, que já se vem admitindo na prática, visto que, em 2015, a Receita Federal substituiu a DIPJ pela ECF.

\section{CONCLUSÃO}

Diante da análise da matéria tratada neste artigo, concernente à possibilidade de o empresário rural pessoa física, inscrito há menos de dois anos no Registro Público de Empresas Mercantis, mas que exerce atividade há mais de dois anos, ajuizar e ter deferida a recuperação judicial, observou-se existir três correntes de entendimento sobre a questão.

Para a primeira, sustentada pela Ministra Nancy Andrighi em seu voto no julgamento do Recurso Especial n ${ }^{\circ}$ 1.193.115/MT, o empresário rural pessoa física, ainda que não inscrito, poderia se utilizar do instituto da recuperação judicial com o fim de reestruturar o seu passivo, considerando a facultatividade do registro e o fato de o produtor rural prescindir da inscrição para ser considerado empresário.

Para a segunda corrente, sustentada notadamente por precedentes do TJ/MT e pelo entendimento mais recente do TJ/BA, o empresário rural necessariamente deve estar inscrito há mais de dois anos no Registro Público de Empresas Mercantis para ajuizar pedido de recuperação judicial. Isso porque, para os defensores desse pensamento, o registro, para o empresário rural, teria natureza constitutiva, e o exercício regular de atividade por mais de dois anos, exigência prevista no caput do art. 48 da Lei $\mathrm{n}^{\circ} 11.101 / 2005$, somente restaria atendido se o empresário exercesse atividade empresária sob registro durante esse período.

Para a terceira corrente, sustentada notadamente por precedentes do TJ/SP e por recente precedente do TJ/RJ, o registro, para o empresário rural, teria natureza declaratória, de modo que o produtor rural exerce atividade empresária desde o momento em que preenchidos os requisitos do art. 966 do Código Civil. Além disso, considerando a facultatividade do registro, ao contrário da disposição existente para os demais empresários, a atividade empresária exercida pelo empresário rural não poderia ser reputada 'irregular'. Para os defensores deste entendimento, ademais, o fato de a Lei $n^{\circ} 11.101 / 2005$ exigir tão somente o exercício de 'atividades' há mais de dois anos, e não de inscrição por esse período, possibilitaria ao empresário rural somar o tempo de exercício de suas atividades antes da inscrição com o tempo posterior ao registro, visando à demonstração de sua regularidade há mais de dois anos. Por fim, em virtude de o parágrafo segundo do art. 48 da Lei n ${ }^{\circ} 11.101 / 2005$ possibilitar ao empresário rural pessoa jurídica provar, por meio diverso da inscrição, o exercício regular de atividade por mais de dois anos, não se poderia dispensar ao empresário rural pessoa física tratamento mais desfavorável.

Por todas as razões expostas pelos defensores de cada corrente, filia-se, aqui, ao entendimento de que o empresário rural deve estar inscrito no Registro Público de Empresas Mercantis à data do pedido, em virtude da atual redação do inc. V do art. 51 da Lei $n^{\circ} 11.101 / 2005$; todavia, a prova da regularidade da atividade empresária rural exercida há mais de dois anos, visando ao atendimento do requisito imposto pelo caput do art. 48 da Lei $\mathrm{n}^{\circ} 11.101 / 2005$, prescinde da comprovação da inscrição do empresário rural pessoa física por esse período, bastando que o 
A recuperação judicial do empresário rural pessoa física: necessidade de prazo mínimo de inscrição no registro público de empresas mercantis

empresário rural comprove, por qualquer meio de prova idôneo, o exercício de atividade econômica organizada para a produção ou a circulação de bens ou de serviços, nos termos do art. 966 do Código Civil, por mais de dois anos.

Não obstante o entendimento ora defendido, observa-se que, em virtude de o próprio STJ ainda não ter se manifestado sobre a controvérsia em questão de forma definitiva, há inconteste insegurança jurídica em relação à matéria, havendo o risco de anulação dos atos praticados nos processos de recuperação judicial em andamento ajuizados por empresários rurais inscritos há menos de dois anos à data do pedido, tornando-se em vão o esforço despendido pelo devedor, e pelos próprios credores, visando ao seu soerguimento.

Adicionalmente, pela análise da atual redação do Projeto de Lei $n^{\circ} 6.279 / 2013$, percebese que, se aprovado com o texto presente, ao invés de possibilitar o acesso à recuperação judicial ao empresário rural não inscrito no Registro Público de Empresas Mercantis - intenção declarada nas justificativas do Projeto de Lei -, a tendência é que a nova disciplina sirva de mais um fundamento para que o empresário rural pessoa física inscrito há menos de dois anos, mas que exerça atividade empresária por tempo superior a dois anos, possa se valer do benefício da recuperação judicial.

Até que seja aprovado o Projeto de Lei no 6.2729/2013, ou mesmo ser inserida no Projeto de Lei $n^{\circ}$ 10.220/2018 alguma disposição acerca da questão, a tendência é que o STJ, considerando a pendência de julgamento de recursos especiais sobre a matéria, consolide jurisprudência sobre o tema e posteriormente, se for preciso, profira julgamento vinculante, como tentou-se fazer, em 2017, com a proposta de afetação dos REsp $n^{\circ} 1.686 .022 / \mathrm{MT}, 1.684 .994 / \mathrm{MT}$ e 1.685.994/MT ao rito de julgamento de recursos repetitivos.

\section{REFERÊNCIAS}

ABRÃO, Nelson. Curso de Direito Falimentar. São Paulo: Editora Saraiva, 1978.

ALMEIDA, Betyna Ribeiro de. Aspectos da teoria jurídica da empresa. Revista de Direito Mercantil, n. 119, pp. 236-254, jul./set., 2000.

ASCARELLI, Tullio. O empresário. Revista de Direito Mercantil, n. 109, jan./mar., pp. 183/ 189, 1998.

ASCARELLI, Tullio. Origem do direito comercial. Revista de Direito Mercantil, n. 103, pp. 87-100, jul./set., 1996.

BAHIA. Tribunal de Justiça do Estado da Bahia. Agravo de Instrumento $\mathrm{n}^{\circ}$ 001339758.2016.8.05.0000. Primeira Câmara Cível. Relator Desembargador Mário Augusto Albiani Alves Junior. Data de Publicação: 09/03/2017.

BAHIA. Tribunal de Justiça do Estado da Bahia. Agravo de Instrumento de $\mathrm{n}^{\circ}$ 016232537.2016.8.05.0909. Terceira Câmara Cível. Relator Desembargador Ivanilton Santos da Silva. Data de Publicação: 04/04/2018.

BEZERRA FILHO, Manoel Justino. Lei de Recuperação de Empresas e Falência: Lei 11.101/ 2005. Comentada artigo por artigo. 11. ed. São Paulo: Revista dos Tribunais, 2016.

BRASIL. Lei n⿳ 10.406, de 10 de janeiro de 2002. Disponível em: http://www.planalto.gov.br/ ccivil_03/LEIS/2002/L10406.htm. Acesso em: 31 mar. 2019. 
BRASIL. Lei no 11.101, de 09 de fevereiro de 2005. Disponível em: http://www.planalto.gov.br/ccivil_03/_Ato2004-2006/2005/Lei/L11101.htm. Acesso em: 31 mar. 2019.

BRASIL. Projeto de Lei $\mathbf{n}^{0} \mathbf{1 0 . 2 2 0}$, de 10 de maio de 2018. Disponível em: https://www.camara.leg.br/proposicoesWeb/fichadetramitacao?idProposicao=2174927. Acesso em: 31 mar. 2019.

BRASIL. Projeto de Lei no 6.279, de 05 de setembro de 2013. Disponível em: https://www.camara.leg.br/proposicoesWeb/fichadetramitacao?idProposicao=590868. Acesso em: 29 mar. 2019.

BRASIL. Receita Federal. Instrução Normativa $\mathbf{n}^{\mathbf{0}} 83$ de 16 de outubro de 2001. Disponível em: http://normas.receita.fazenda.gov.br/sijut2consulta/link.action?visao=anotado\&idAto= 14387. Acesso em: 31 mar. 2019.

BRASIL. Superior Tribunal de Justiça. AResp no 896.041/SP. (2016/0086265-2). Decisão Monocrática. Min. Relator: Marco Aurélio Belizze. Data de Publicação: 12/05/2016.

BRASIL. Superior Tribunal de Justiça. ProAfR no REsp no 1.684.994/MT. 2017/0176137-8. Segunda Seção. Min. Relator: Luis Felipe Salomão. Data de Julgamento: 28/11/2017. Data de Publicação: 05/12/2017.

BRASIL. Superior Tribunal De Justiça. REsp nº 1.193.115/MT. Terceira Turma. Relatora Ministra Nancy Andrighi, Relator p/ Acórdão Ministro Sidnei Beneti. Data de Julgamento: 20/08/ 2013. Data de Publicação: 07/10/2013.

CAVALli, Cássio. Direito Comercial: Passado, Presente e Futuro. Rio de Janeiro: Elsevier, 2012.

CENTRO DE ESTUDOS JUDICIÁRIOS DO CONSELHO DA JUSTIÇA FEDERAL. III Jornada de Direito Civil. Enunciado $n^{\circ}$ 198. Brasília/DF, 2005. Disponível em: https:// www.cjf.jus.br/cjf/corregedoria-da-justica-federal/centro-de-estudos-judiciarios-1/publicacoes1/cjf/corregedoria-da-justica-federal/centro-de-estudos-judiciarios-1/publicacoes-1/jornadascej/iii-jornada-de-direito-civil-1.pdf. Acesso em: 28 mar. 2019.

COMPARATO, Fábio Konder. Perfis da Empresa. Revista de Direito Mercantil, n. 104, pp. 116-117, out./dez., 1996. Tradução do original: ASQUINI, Alberto. Profilli dell'impresa. Rivista di Diritto Commerciale, 1943, v. 41, I.

CONFEDERAÇÃO DA AGRICULTURA E PECUÁRIA NO BRASIL. Panorama do Agro. Disponível em: https://www.cnabrasil.org.br/cna/panorama-do-agro. Acesso em: 27 mar. 2019.

DINIZ, Gustavo Saad. Produtor rural. Enciclopédia jurídica da PUC-SP. Celso Fernandes Campilongo, Alvaro de Azevedo Gonzaga e André Luiz Freire (coords.). Tomo: Direito Comercial. Fábio Ulhoa Coelho, Marcus Elidius Michelli de Almeida (coord. de tomo). 1. ed. São Paulo: Pontifícia Universidade Católica de São Paulo, 2017. Disponível em: https://enciclopediajuridica.pucsp.br/verbete/211/edicao-1/produtor-rural. Acesso em: 28 mar. 2019.

FRANÇA, Erasmo Valladão Azevedo e Novaes. Empresa, Empresário e Estabelecimento: A Nova Disciplina das Sociedades. In: Temas de Direito Societário, Falimentar e Teoria da Empresa. São Paulo: Malheiros Editores, 2009.

GONÇALVES NETO, Alfredo de Assis. Direito de empresa: Comentários aos arts. 966 a 1.195. 6. ed. São Paulo: Revista dos Tribunais, 2016, n. XVII.

GONÇALVES NETO, Alfredo de Assis. Parecer jurídico juntado às fls. 482/502 dos autos do Agravo de Instrumento no 2005580-50.2018.8.26.0000, interposto por "Tangará Importadora e 
A recuperação judicial do empresário rural pessoa física: necessidade de prazo mínimo de inscrição no registro público de empresas mercantis

Exportadora S/A" em face de "José Serra Netto - ME", em trâmite junto à $1^{\text {a }}$ Câmara Reservada de Direito Empresarial do Tribunal de Justiça do Estado de São Paulo, mediante consulta do advogado Ivo Waisberg. Curitiba/PR. Assinado em: 30 jun. 2016.

LIMIRO, Renaldo. Marcantes Alterações na Lei de Recuperação Judicial. Rota Jurídica. Publicado em: 16 out. 2017. Disponível em: https://www.rotajuridica.com.br/coluna_2/marcantes-alteracoes-na-lei-de-recuperacao-judicial/. Acesso em: 31 mar. 2019.

MATO GROSSO. Tribunal de Justiça do Estado do Mato Grosso. Agravo Regimental $\mathrm{n}^{\circ}$ 0094921-12.2016.8.11.0000. Primeira Câmara Cível. Des. Relatora: Desa. Nilza Maria Pôssas de Carvalho. Data de Julgamento: 08/11/2016. Data de Publicação: 14/11/2016.

MATO GROSSO. Tribunal de Justiça do Estado do Mato Grosso. Agravo de Instrumento $\mathrm{n}^{\circ}$ 0074859-48.2016.8.11.0000. Quinta Câmara Cível. Des. Relatora: Cleuci Terezinha Chagas Pereira da Silva. Data de Julgamento: 07/12/2016. Data de Publicação: 13/12/2016.

NETTO, Ângelo Guerra. Aspectos da Reforma da Lei de Recuperação Judicial. Jota. Publicado em: 25 set. 2019. Disponível em: https://www.jota.info/opiniao-e-analise/artigos/aspectos-dareforma-da-lei-de-recuperacao-judicial-25092017. Acesso em: 31 mar. 2019.

RIO DE JANEIRO. Tribunal de Justiça do Estado do Rio de Janeiro. Mandado de Segurança de no 0019729-80.2018.8.19.0000. 22ª Câmara Cível. Des. Relator Carlos Eduardo Moreira da Silva. Data de Julgamento: 06/11/2018.

SÃO PAULO. Tribunal de Justiça do Estado de São Paulo. Agravo de Instrumento no 2152473 10.2018.8.26.0000. 1 ${ }^{a}$ Câmara Reservada de Direito Empresarial. Relator Desembargador Hamid Bdine. Data de Publicação: 09/11/2018.

SÃO PAULO. Tribunal de Justiça do Estado de São Paulo. Agravo de Instrumento no 2048349 10.2017.8.26.0000. $2^{a}$ Câmara Reservada de Direito Empresarial. Trecho do voto do Exmo. Relator Desembargador José Araldo da Costa Telles. Data de Julgamento: 30/10/2017.

SÃO PAULO. Tribunal de Justiça do Estado de São Paulo. Agravo de Instrumento no 2037064 59.2013.8.26.0000. $2^{\text {a }}$ Câmara Reservada de Direito Empresarial. Relator Desembargador José Reynaldo. Data de Julgamento: 22/09/2014.

SERASA EXPERIAN. Indicadores Econômicos: Recuperações Judiciais Requeridas. Disponível em: https://s3-sa-east-1.amazonaws.com/serasaexperian-site-institucional-wp-content/wpcontent/uploads/2019/03/12124217/FACONS.zip. Acesso em: 29 mar. 2019.

STAJN, Raquel. Comentários ao art. 48. In: SOUSA JR., Francisco Satiro de; PITOMBO, Antônio S. A. de M. (Coord.). Comentários à Lei de Recuperações e Falência. $2^{a}$ ed. São Paulo: RT, 2007.

WAISBERG, Ivo. A Viabilidade da Recuperação Judicial do Produtor Rural. Revista do Advogado. Ano XXXVI, out./2016, n. 131, pp. 83-90, 2016.

Recebido em: 31 mar. 2019.

Aceito em: 3 jun. 2019. 